\title{
The Influence of Tax Legislation in Promoting Downstream Beneficiation in the South African Mining Sector
}

\author{
Debra-Ann Katrina Collyer, Daniel Petrus Schutte*, Pieter Van der Zwan \\ North-West University, Potchefstroom, South Africa \\ Email: *danie.schutte@nwu.ac.za
}

How to cite this paper: Collyer, D.K., Schutte, D.P. and Van der Zwan, P. (2018) The Influence of Tax Legislation in Promoting Downstream Beneficiation in the South African Mining Sector. Theoretical Economics Letters, 8, 166-176.

https://doi.org/10.4236/tel.2018.82012

Received: December 19, 2017

Accepted: February 4, 2018

Published: February 7, 2018

Copyright (C) 2018 by authors and Scientific Research Publishing Inc. This work is licensed under the Creative Commons Attribution International License (CC BY 4.0).

http://creativecommons.org/licenses/by/4.0/

\begin{abstract}
Downstream beneficiation in the South African mining industry is promoted in the Mineral and Petroleum Resources Development Act. This research evaluated the influence of existing tax and royalty legislation in promoting downstream beneficiation, and the economic decisions of mining companies to respond to the benefits provided for in the legislation. The research commenced with a theoretical analysis of tax and royalty legislation to determine existing provisions in the law that could stimulate the process of downstream beneficiation, or alternatively discourage potential beneficiators, or frustrate the activities of existing refiners. Role players in industry were engaged to analyze tax incentives in legislation that influence the economic decision making of the extractors in response to the legislation either supporting or deterring downstream beneficiation in their value chain. The data obtained from the extractors were analyzed and interpreted to determine how tax legislation has influenced the promotion of beneficiation in the South African mining sector. The research found that tax legislation influenced some of the extractors to a limited extent, indicating that the intent of tax legislation to promote beneficiation was not consistently achieved. It was further observed that the available incentives did not have a sufficiently decisive impact on the extractors to beneficiate; however it was also determined that tax legislation indeed has the ability to promote beneficiation in the South African mining industry. Finally, tax legislation was not found to discourage refining activities. It is recommended that further studies be conducted to determine whether tax incentives are too simplistic to effectively apply in all circumstances or whether more advanced formulas are required based on the various types of minerals beneficiated.
\end{abstract}

\section{Keywords}

Mining Sector, Tax Incentives, Mineral Royalties, Refined Mineral Resources, 
Downstream Beneficiation

\section{Introduction}

The discovery of gold and other minerals played an important part in the growth of the South African economy. The South African mining industry accounts for $8 \%$ of the gross domestic product and $11 \%$ of the world's gold reserves [1]. South Africa has the largest reserves of platinum, manganese, chromite and gold in the world and is currently ranked fifth in terms of mining contribution to gross domestic product [2]. The mining industry contributes significantly to the South African economy through increased tax revenues generated and the positive impact of the industry on the balance of payments of the country [3]. However, the last decade has seen the decline of its relative contribution to the economy, due to several contributing factors such as weakening commodity prices, escalated cost of labor and production, labor unrest, and increased taxes [4].

More than a decade has passed since the State exercised its right to the sovereignty of all South Africa's privately held mineral resources. This right was exercised through the introduction of the Mineral and Petroleum Resources Development Act (MPRDA), which impacted several stakeholders, including government, the public sector, the mining industry as a whole, mining companies, as well as current and potential investors [5]. The MPRDA, promulgated in 2002, states that South Africa's mineral resources are the communal heritage of the people of South Africa, whereby the State acts as the custodian of this wealth for the benefit of the people.

In order to compensate the people of South Africa for the loss of mineral wealth arising from the extraction of minerals from the soil, the Mineral and Petroleum Resources Royalty Act (MPRRA, the Royalty Act) was legislated in 2011. The Explanatory Memorandum for the Royalty Act [6] explains that the Royalty Act seeks to compensate the State financially for the permanent loss of the country's non-renewable resources by way of a royalty tax levied on the transfer of mineral resources extracted from South African soil.

The Royalty Act distinguishes between refined and unrefined mineral resources, and sets out different royalty formulae which must be applied to mineral resources and circumstances, resulting in an obligation payable to the Commissioner.

\section{Downstream Beneficiation}

The process whereby value is added to an unrefined mineral resource extracted from the ground is known as beneficiation [7]. Beneficiation involves the transformation of a primary material to a more finished product [8]. The additional level of processing increases the revenue gained from the exploitation of the 
mineral resource, as well as significantly increases the labor absorptive capacity of the industry [9]. It has a valuable impact on South Africa's critical infrastructure, its backward and forward knowledge, its labor force and gross domestic product [8]. Downstream beneficiation is promoted in the MPRDA, by the Department of Mineral Resources, the South African Mining Charter of 2004, the Precious Metals Act 2005, Act No 37 of 2005, the Diamonds Act, Act No 56 of 1986, the Mineral Beneficiation Framework for Africa and the Minerals and Mining Policy for South Africa, 1998. One of the methods that the South African Government can stimulate the process of beneficiation is through the introduction of tax incentives [9].

Tax incentives can encourage investment in the infrastructure required to beneficiate minerals, or through tax allowances in respect of the expenditure required for research and development, or the reduced rate of royalty taxes for refined mineral resources. Royalty taxes can influence mining companies' economic decisions and behavior [10]. The intention of the lower royalty rate is to promote downstream beneficiation [6]. This was to be achieved through the higher factor provided in the royalty rate mechanism for refined mineral resources, which was understood to result in a lower royalty payable for this type of resource.

However, the royalty mechanism contained in the MPRRA is unlikely to consistently result in the same royalty amount, irrespective of whether or not a mineral resource has been refined, which may be detrimental to promoting downstream beneficiation [11]. Furthermore, the royalties on refined mineral resources can in certain circumstances be significantly higher than those on unrefined mineral resources. It is therefore questionable if the extractor is indeed incentivized, where in certain circumstances the royalty payable on refined minerals exceeds that payable on unrefined minerals. This situation would discourage extractors from processing the mineral resource beyond its unrefined state.

It is also suggested that the royalty regime is unlikely to motivate miners to become refiners, as the benefit of the reduced rate on refined minerals appears to be insufficient to justify the additional costs to refine the mineral resource to the prescribed state of beneficiation [12]. The process of beneficiation requires investment in research and development by the extractors, is capital intensive, and it may take many years before the subsequent gross sales of the refined minerals are realized.

South Africa has abundant mineral reserves [13] and has the potential to raise the level of beneficiated mineral output, in particular with regards to the production of finished goods [9]. However, beneficiation in South Africa has been on the decrease and consequently South Africa is now faced with the challenge of beneficiating its minerals [14]. It is unclear whether the South African government has been effective in promoting downstream beneficiation through the use of tax incentives. This gap in the literature prompted this in-depth research to evaluate the influence that royalty legislation, implemented in 2011, had on promoting downstream beneficiation, as well as other incentives provided for in 
tax legislation applicable to the process of beneficiation.

\section{Methodology}

As information on the influence of taxes on beneficiation from the perspective of the extractor are not readily available, it was necessary to obtain an in-depth understanding of the views of extractors on the influence of tax legislation in promoting downstream beneficiation in their company. In order to fully understand the extent to which tax incentives have played a role in the decision making, the extractors themselves needed to be consulted through interviews. This method provided the opportunity to probe beyond the initial responses and rationale received by the extractors, which produces more in-depth and comprehensive information [15]. The interview process provided the benefit of timely responses from participants and provided the opportunity to explain the purpose of the enquiry. Moreover, it was possible to engage the extractors more actively and it allowed the participants the opportunity to raise concerns and to discuss any matters in more detail.

Samples for qualitative research are generally much smaller than those used in quantitative research as the former is concerned with meaning, and not making generalized hypothesis. One thread of data is all that is needed to ensure that it becomes part of the analysis framework [16]. A small number of cases may be adequate for a research project when studying hard to access populations such as elites [17]. In these cases, between six and a dozen participants may offer insights into the corporate boardroom.

The geographical area covered in the sample included resident extractors whose activities are conducted in South Africa's land and sea. The choice of extractor was greatly influenced by the willingness of extractors to participate in the research and communications with extractors began in May 2015 to ascertain the extent of initial extractors that were willing to participate in the research. Initially, six extractors confirmed their willingness to participate in various communications. One of the initial extractors subsequently became unable to participate, however, an additional extractor was later obtained so that the sample size remained at six.

The demographics of the respondents included relevant information such as the age of the mining operations, number of years refining minerals, the type of minerals extracted, provinces in which the respondents operate, annual gross turnover as well as the designations and qualifications of the respondents. The results reflected that the respondents had conducted mining operations from 5 years to over 20 years, thus both new and experienced refiners' responses were included in the research. The types of minerals covered by the mining company respondents were calcium fluoride, chrome, coal, cobalt, copper, diamonds, dolomite, filter sand, fluorspar, gold, limestone, nickel and platinum. The numerous diverse types of minerals included in the sample ensured a wide spread of the population. 
Many geographical regions were represented by the sample. The provinces of Gauteng, Limpopo, Mpumalanga, the Northern Cape and the North West are represented in the sample obtained, whilst certain mining companies operate mines in multiple provinces. The high level of the positions of authority of the respondents provided a good level of assurance of the quality of the answers and the high educational levels provided assurance that informed and educated responses were received. The annual gross turnover of the respondents indicated that a wide spread of mining companies were included in the sample with turnover ranging from under R150 million to over R10 billion.

\section{Results and Findings}

The research endeavored to find the answer to the influence that tax legislation has had on promoting downstream beneficiation in the South African mining sector.

\subsection{Influence of Taxes on Refining Activities}

The respondents were provided with the opportunity to express their views on the influence that tax legislation had on promoting downstream beneficiation in their entity. The information obtained commenced with determining the contribution of mining beneficiation to the economy, and then continued on to the underlying decision making. Taxes in general were then discussed followed by specific taxes and tax incentives. Specific taxes included royalty taxes and a discussion of the royalty rate formula and Schedule 1 of the MPRRA. Other tax incentives were then discussed, including the section 12I tax incentive allowance, the capital expenditure allowance, research and development allowance, export taxes, and alternative tax incentives. These questions were asked in order to demonstrate the ability of tax legislation to promote beneficiation to the South African mining industry.

\subsection{Benefit to the Economy}

The first part of the research examined the contribution of the process of beneficiation to the economy through increased taxation due and the positive impact on the economy through the increase in South Africa's labor force. The majority of the extractors were of the opinion that the process of beneficiation had increased the amount of tax payable and created additional jobs. These combined results signified the importance of the labor-intensive process of beneficiation that is vital to the economy, and why it is essential for government to encourage extractors to beneficiate.

\subsection{Measurement of Impact of Tax Incentives}

The research confirmed that the majority of extractors carried out mineral project feasibility studies on extending trade to include downstream beneficiation as a result of tax incentives, including the establishment of a baseline to 
measure the possible impact of tax incentives. It was further confirmed that this information assisted the extractors in making informed decisions on tax incentives, and informed answers for the purposes of this research.

\subsection{Understanding of the Workings of a Tax Incentive}

The extractors confirmed their understanding of the formula and agreed with the mathematical workings of the royalty formula identified in the literature review that the process of beneficiation decreases the royalty rate percentage payable to the Commissioner due to the workings of the dual rate formula.

\subsection{Incentives That Encouraged Extractors}

Four extractors were encouraged to beneficiate due to the section 12I tax allowance incentive relating to new industrial projects and expansions or upgrades of existing industrial projects. One of the extractors advised that they have invested in new infrastructure and employment as they consider the section 12I incentive as a means to improve the return on their beneficiation project. The researcher concluded that the section 12I tax allowance incentive had encouraged the majority of extractors to refine mineral resources. This demonstrated that the allowance is mainly successful in influencing new industrial projects or existing industrial projects in the mining industry relating to beneficiating mineral resources.

Most of the extractors agreed that the lower percentage for refined mineral resources is sufficient to promote downstream beneficiation whilst the extractors were neutral that the possible introduction of export taxes on the exports of un-beneficiated products would encourage their company to beneficiate products that are currently exported as unrefined minerals.

It was therefore evident that the section 12I tax incentive, the dual rate formula and the possible imposition of export taxes encouraged some extractors, but not a clear majority of the extractors to beneficiate.

\subsection{Incentives Where Extractors Were Divided}

Approximately one third of the extractors considered that taxes can encourage new investment into beneficiation while other extractors were divided on the matter. Due to the sample of participants ranging from new to experienced beneficiators, and representing many geographical regions, as well as numerous types of minerals resources beneficiated, the individual perceptions of each of the extractors were similarly diverse. Due to the differences in opinion of the extractors further research is recommended to determine whether tax incentives are too simplistic to effectively apply in all circumstances or whether more advanced formulas are required based on the various types of minerals beneficiated. The literature review stated that tax incentives available would need to have a decisive impact on the extractors to encourage new beneficiation. One of the extractors explained that there is a vast market for uncut diamonds, whereas 
there is only a smaller market for polished diamonds, as they sell very slowly in South Africa. In these circumstances, it is questionable whether the miner of this type of mineral resource, even with incentives available, would choose to beneficiate the uncut diamonds. It is therefore possible that the available incentives do not have a sufficiently decisive impact on the extractors to beneficiate, and the extractors require greater incentives to motivate them to invest in the capital required to beneficiate. Many extractors advised that a proper beneficiation policy needs to be supported by tax legislation, infrastructure and Trade and Industry programs.

Varied results were obtained from the extractors as to whether the dual rate mechanism in the MPRRA has promoted value added activities in their company. As the results were divided, further research is required relating to how the dual rate formula affects different types of mineral resources. It also appears that the intention of the lower royalty rate for refined minerals to promote downstream beneficiation was not consistently achieved. One of the extractors explained that the refining process requires an advanced infrastructure, and in order to refine a mineral for the first time, there would need to be a large capital layout to build the plant and machinery required for the process. Discussions with extractors revealed that profits generated from exporting the mineral resource in its raw form without beneficiating the products are higher than the profits generated through domestic beneficiation. The dual rate formula had influenced certain extractors, however, as it had not consistently promoted beneficiation, the influence was not necessarily as intended by the MPRRA.

Moreover, the extractors have differing opinions regarding the effect of the discontinuance of the upfront capital expenditure write off on their refining activities. This demonstrated that the upfront capital expenditure write off is not a consistent motivator of the process of beneficiation.

The majority of extractors did not make use of the research and development incentive with regards to beneficiation in their companies. This demonstrates that the research and development tax incentive has not been utilized by the majority of participant extractors to refine mineral resources and does not successfully motivate the majority of extractors to refine mineral resources.

Due to these varied results, further discussions were held with the extractors. One of the extractors advised that they were of the opinion that tax incentives are clearly designed to incentivize particular mining sectors, of which they were not one of the fortunate recipients. On the other hand, another extractor that developed a R1.2 billion beneficiation plant, advised that the process was promoted through both the growing demand in the South African market and government's support initiative for their multiple downstream levels and value added processes. To put these differing opinions into perspective, it was determined that the latter extractor enjoys an exponential increase in the value of the mineral resource after it has gone through processing. This information revealed that the type of mineral to be beneficiated is of such importance that it can de- 
termine whether tax legislation is of benefit to the potential refiner or not.

\subsection{Incentives Do Not Discourage Extractors}

The majority of extractors did not perceive tax legislation to discourage existing value-added activities. It was revealed that the majority of extractors were of the view that the MPRRA in particular had not discouraged their refining activities. It was also evident that tax and royalty legislation have not discouraged refiners from beneficiating minerals.

\subsection{Financial Estimates}

The extractors were divided as to the percentage increase in earnings before interest and taxation and the percentage of sales price that refinement costs represent. The answers received reflected the diverse nature of the type of operations due to the various different types of minerals beneficiated. One of the extractors provided an insight into their choice of percentage increase in earnings. The extractor stated that after the initial setup cost of beneficiation, there are other main cost factors. One of the major cost factors is the daily cost of energy. In South Africa, the supply of energy is erratic due to load shedding, which could halt production capabilities. These expenses have a direct impact on the earnings of the company due to the process of refinement. Another main cost incurred by the extractor due to the process of beneficiation is the production cost, of which the main portion is labor cost. The extractor referred to the current wage negotiations, and explained that the increases in wage costs directly impacted on the net earnings resulting from beneficiated products, which is labor intensive due to its nature. A further factor that the extractor pointed out is that the cost of beneficiating their product in India or China was substantially less than the cost of local beneficiation.

The extractors were of the opinion that the expected increase in their turnover if alternate incentives were provided by government would be in the $1 \%$ to $19 \%$ range. The results indicated that tax legislation does have the ability to increase turnover, in the opinion of the extractors, and therefore encourage the process of beneficiation.

\subsection{Practicality of the Tax Legislation}

It was found that the majority of the extractors disagree that it is practical to apply the different distinctions between a refined and unrefined mineral resource as required by Schedule 1 of the MPRRA. The response confirmed the challenges with the various types of minerals that are beneficiated.

\subsection{Discussions with Extractors}

On discussing the issue of beneficiation with the extractors, it was determined that the extractors can get very passionate about this topic, with all the participant extractors supporting government's initiative to beneficiate domestically. 
However, this support did not necessarily result from tax incentives provided by the government.

Discussions with extractors revealed that the incentives provided by government would need to be more than favorable to counter the problems and costs associated with beneficiation before the mining industry would turn to these incentives.

The extractors explained that certain types of minerals lend themselves better to beneficiation than others. They further explained that the different types of industries needed to be considered when designing tax incentives, as an industry that refines base metals enjoys a relatively straight forward process as it is comparatively easier to beneficiate the ore. The extractors believed that a more effective system to promote beneficiation would need to differentiate between copper and diamonds as an example. If this approach was used, they believed that there would be a better chance of incentivizing the industry. One of the extractors advised that they have been working with the Chamber of Mines to investigate proposed measures to declare certain mineral resources as strategic, and to encourage local beneficiation of these minerals. The extractors also felt that it was important to mention the South African steel industry, and express concern that government was not effective in saving this industry, which beneficiates raw iron ore and manganese into steel. This non-renewable mineral resource which is considered to be of exceptional quality is now sadly exported from South Africa in its raw form without beneficiating the mineral.

\section{Conclusions}

The research revealed that available tax and royalty incentives do influence some extractors; however these incentives do not consistently achieve their objectives. The research found that the incentives do not have a sufficiently decisive impact on extractors to encourage beneficiation, revealing that they are limited in their application.

Although the results were often divided as to whether tax incentives have promoted or discouraged beneficiation in their entities, this study has demonstrated the ability of tax legislation to promote beneficiation in the South African mining industry.

The main contribution of the study is the valuable insight and feedback obtained from extractors regarding beneficiation in the South African mining industry. The results revealed that tax legislation is too simplistic to effectively promote beneficiation in all circumstances due to the diverse types of minerals beneficiated by the respondent extractors. In this regard, it is recommended that more advanced tax legislation is required based on the various types of minerals beneficiated.

From a practical perspective, the research is particularly valuable as it provides information on the current views of extractors in the context of the promotion of beneficiation by tax legislation. This information can therefore be of benefit to 
both extractors and the State, as a possible gap exists between the various role players.

\section{Limitations and Recommendations for Future Research}

Although a diverse range of respondents were included, the limitation of the study is that the specified group of respondents may have had different experiences from other extractors due to their specific circumstances. These circumstances may include varying extent of operations, different geographical regions, different mineral resources beneficiated, varying levels of investment required for beneficiation of their raw materials and different positions and viewpoints within the entity. Future studies may therefore focus on extractors with different circumstances and countries with different tax legislation pertaining to beneficiation. In addition, future studies may focus on the actual financial impact and related calculations of beneficiation in the mining industry.

\section{References}

[1] Kane-Berman, J. (2017) Mining in SA: Then, Now, and into the Future-IRR. http://www.politicsweb.co.za/archive/mining-in-sa-then-now-and-into-the-future-irr

[2] Wits Mining Institute (2016) The South African Mining Industry. https://www.wits.ac.za/wmi/about-us/the-south-african-mining-sector/

[3] Davis Tax Committee (2015) First Interim Report on Macro Analysis for the Minister of Finance. The Tax System and Inclusive Growth in South Africa. The Davis Tax Committee, Pretoria, 26-29, 43.

[4] BMI Research (2017) Industry Trend Analysis-South Africa's Mining Recovery to Be Short-Lived. FitchGroup Company. http://www.mining-insight.com/industry-trend-analysis-south-africas-mining-reco very-be-short-lived-apr-2017

[5] Grobler, J. (2014) The Mineral and Petroleum Resources Royalty Act: the impact on the fiscal and mining industry in South Africa. Dissertation, University of Pretoria, Pretoria, 2.

[6] National Treasury (2002) Explanatory Memorandum for the Minerals and Petroleum Resources Royalty Act 28 of 2002. Government Printer, Pretoria, 2-26.

[7] Department of Mineral Resources (1998) White Paper: A Minerals and Mining Policy for South Africa. Government Printer, Pretoria, 28.

[8] Department of Mineral Resources (2011) Beneficiation Strategy. http://www.dmr.gov.za/publications/summary/162-beneficiation-strategy-june-201 1/617-beneficiation-strategy-june-2011-.html

[9] Department of Mineral Resources (2015) Beneficiation Economics. http://www.dmr.gov.za/beneficiation-economics.html

[10] Mitchell, P. (2016) Taxation and Investment Issues in Mining. https://www.oecd.org/site/devaeo10/44282904.pdf

[11] Nel, P. and Van der Zwan, P. (2010) The Impact of the Minerals and Petroleum Resources Royalty Act on the South African Mining Industry: A Critical Analysis. Meditari Accountancy Research, 18, 89-103.

[12] Cawood, F. (2004) The Mineral and Petroleum Resources Development Act of 2002: 
A Paradigm Shift in Mineral Policy in South Africa. Journal of the South African Institute of Mining and Metallurgy, 104, 53-64.

https://www.saimm.co.za/Journal/v104n01p053.pdf

[13] King, E. (2012) The State Intervention in the Minerals Sector Report-Mining Tax and Nationalisation. South African Institute of Tax Practitioners.

http://www.thesait.org.za/news/?id=4745

[14] Busia, K. and Akong, C. (2017) The African Mining Vision: Perspectives on Mineral Resource Development in Africa. Journal of Sustainable Development Law and Policy, 8, 145-180. https://doi.org/10.4314/jsdlp.v8i1.7

[15] Hargie, O. and Dickson, D. (2004) Skilled Interpersonal Communication, Research, Theory and Practice. 4th Edition, Routledge, London, 138.

[16] Ritchie, J. and Lewis, J. (2003) Qualitative Research Practice: A Guide for Social Science Students and Researchers. Sage Publications, London, 84.

[17] Baker, S. and Edwards, R. (2012) How Many Qualitative Interviews Is Enough. Discussion Paper, National Centre for Research Methods, Southampton, 8. 